\title{
SOCIEDADE CIVIL E "TERCEIRO SETOR': apropriações indébitas do legado teórico-político de Gramsci
}

\author{
Civil society and "third sector": embezzlement \\ of the theoretical-political legacy of Gramsci
}

\section{Marcos Francisco Martins}

Doutor em História e Filosofia da Educação pela Unicamp. Coordenador do Programa de Mestrado em Educação do Unisal Americana, SP - Brasil, e-mail: marcosfranciscomartins@ gmail.com

\begin{abstract}
Resumo
$\mathrm{O}$ presente artigo discute a emergência da sociedade civil como um conceito-chave para se compreender a dinâmica da atual fase de desenvolvimento do capitalismo no Brasil e seu processo de reestrutura das relações produtivas e sociais. Em busca da identificação da gênese desse conceito, são aqui apresentadas as acepções contratualistas, hegeliana e marxiana. Contudo, o objetivo fundamental é o de contestar a leitura que alguns dos novos atores sociais têm feito desse termo, especificamente aqueles que se auto-intitulam como integrantes do "terceiro setor". Isso porque muitos desses sujeitos sociais procuram indebitamente ancorar no legado teórico-metodológico e político gramsciano suas posições idealistas e liberais, tidas equivocadamente como neutras sob o ponto de vista ético, político e ideológico.
\end{abstract}

Palavras-chave: Antonio Gramsci; Norberto Bobbio; Sociedade Civil; Terceiro Setor. 


\section{Abstract}

The present article discusses the emergency of the civil society as a key concept to comprehend the dynamics of the actual developmental phase of capitalism in Brazil and the process of restructuring the productivity and social relations. In search of the geneses identification of this concept, here it is presented its accepted contratualist, Hegelians and Marxists. However, the fundamental objective is to question the literature that some new social actors have done with this term, specifically those that self entitled themselves as members of the "third sector". Because many of these social subjects indebtely attempt to anchor in the theoretical-methodological and political gramscian and their idealist and liberal positions, equivocally taken as neutral by the ethical, political and ideological point of view.

Keywords: Antonio Gramsci; Norberto Bobbio; Civil Society; Third Sector.

\section{Introdução}

O conteúdo do presente texto originou-se das reflexões acerca do conceito de "sociedade civil" que se está empreendendo para subsidiar o projeto de pesquisa denominado "Mapeamento da Educação sociocomunitária na região de Campinas", atualmente em desenvolvimento no âmbito do Mestrado em Educação do Centro Universitário Salesiano de São Paulo - Unisal -, a partir do projeto de pesquisa "Intervenções educativas sociocomunitárias".

Com o objetivo de contestar a identificação que hoje muitos protagonistas de ações sociais fragmentárias e auto-intituladas neutras política e ideologicamente fazem entre "sociedade civil" e "terceiro setor", o texto que se segue divide-se em três partes. Na primeira, são apresentadas algumas considerações sobre a origem do conceito de "sociedade civil". Retomam-se com brevidade a sua acepção contratualista, a noção que Hegel tem dele, a formulação marxiana e a marxista de perspectiva gramsciana.

Por sua vez, a segunda parte inicia-se com a assertiva de que a "sociedade civil" está sendo revigorada contemporaneamente. E toda a sua legitimidade diz respeito à acepção hodierna que dela se tem como a ("nova" - 
?) arena das ações sociais e/ou como um conjunto de ("novos" - ?) atores sociais. Estas duas definições de "sociedade civil", porém, aproximam-se na medida em que se baseiam em duas negativas, quais sejam: a de seu não-compromisso ideológico, próprio do neoliberalismo de "terceira via" que a sustenta teóricofilosófica e ético-politicamente; e a de sua não-vinculação com o Estado e com o mercado, da qual resulta a sua identidade como "terceiro setor".

Por fim, na terceira parte, é sustentada a idéia de que usar o conceito de "sociedade civil" na acepção que ele adquiriu no interior do pensamento gramsciano para identificar o assim chamado "terceiro setor" é uma apropriação indébita e "interesseira". Indébita porque a formulação que Gramsci tem desse termo não abre espaço para a neutralidade ético-política e ideológica e nem, muito menos, para identificá-lo como independente do Estado e do mercado, a não ser que se tenha uma leitura idealista-liberal do pensamento gramsciano, tal como Bobbio. E "interesseira" porque a identificação hoje corrente entre "sociedade civil" e "terceiro setor" tornouse um elemento importante na disputa pela hegemonia sobre o modelo de sociabilidade, que no Brasil de hoje não é outro senão aquele afeito aos interesses e necessidades do desenvolvimento do capital, sua valorização e acumulação cada vez mais ampliadas, que nada tem de gramsciano.

\section{Aproximações do conceito de "sociedade civil" e da sua acepção gramsciana}

$\mathrm{Na}$ atualidade, o termo "sociedade civil" tem marcado presença no vocabulário corrente de diferentes atores sociais, como cientistas políticos, educadores, jornalistas, aqueles do chamado "setor coorporativo" principalmente os que integram os institutos e fundações das empresas privadas -, movimentos sociais organizados, ONGs - Organizações Não-governamentais -, entre outros. Invariavelmente, a palavra "sociedade civil" tem sido utilizada para designar ações que se auto-identificam como promovidas por "agentes privados para fins públicos" (FERNANDES, 1994, p. 21).

Contudo, na sua origem, esse foi o termo empregado pelos pensadores modernos - inicialmente por Hobbes e posteriormente por Locke, Rousseau e Kant - para demarcarem as novas relações sociais que surgiram com a superação do "estado de natureza", momento em que os homens primitivos se encontravam submetidos às leis naturais e, conseqüentemente, em conflitos constantes porque "todo mundo [tinha] o poder executivo da lei da natureza" (LOCKE, 1991, p. 220). 
Essa concepção contratualista ${ }^{1}$ - que não é unívoca, pois traz numa mesma estrutura conceitual teorias muito diversas entre si (BOBBIO; MATTEUCCI; PASQUINO, 1992, p. 272) -, em sentido amplo, entende que novos contornos sociais resultaram do contrato firmado entre os homens, uma vez que ele deu origem ao Estado, um novo e significativo elemento protagonista na demarcação da dinâmica societária. Nesta acepção, "sociedade civil" torna-se sinônimo da evolução política do homem, da conquista da "civilização" alcançada graças ao abandono do "estado de natureza" e a conseqüente constituição da sociedade política mediante um acordo "para racionalizar a força e alicerçar o poder no consenso" (BOBBIO; MATTEUCCI; PASQUINO, 1992, p. 272).

Assim compreendidas, as relações sociais passaram a ser vistas como reguladas não mais pelos impulsos individuais dos sujeitos em defesa de seus interesses, numa "luta de todos contra todos", uma generalizada guerra social, mas por complexos mecanismos políticos criados pela humanidade "por consentimento na comunidade" (LOCKE, 1991, p. 225). Desta feita, a sociedade política ou Estado é concebido como um conjunto de instrumentos de regulação social que promove a passagem do estado de natureza a um novo padrão de funcionamento das relações sociais, no qual são garantidas a paz, a liberdade, a segurança e a propriedade, tidas pelos pensadores modernos como fundamentais à convivência civilizada.

Exceção deve ser feita, porém, às formulações de Rousseau. Como se sabe, mesmo sendo identificado como contratualista, ele exalta o "bom selvagem", porquanto entende que "A essência, a natureza do homem é essencialmente boa" (FORTES, 1989, p. 32 - grifo do autor) e, ao mesmo tempo, ataca a "civilização", que tem para ele uma conotação negativa porque promove a "degenerescência dessa natureza originária" (idem). E para se diferenciar ainda mais dos outros contratualistas, nomeadamente de Hobbes e Locke (para quem "sociedade civil" e sociedade política ou civilizada são a mesma coisa, isto é, superação do estado de natureza), Rousseau faz uma distinção entre "sociedade civil" - ou civilizada -, que degenerou a natureza humana, e sociedade política, que deverá surgir do contrato social e superará a degenerescência a que o homem foi submetido com a corruptora civilização (BOBBIO; MATTEUCCI; PASQUINO, 1992, p. 1207-1208).

1 Segundo Renato Janine Ribeiro, “contratualista, quer dizer, um daqueles filósofos que, entre os séculos XVI e o XVIII (basicamente), afirmaram que a origem do Estado e/ou da sociedade está no contrato: os homens viveriam, naturalmente, sem poder e sem organização - que somente surgiriam depois de um pacto firmado por eles, estabelecendo as regras de convívio social e de subordinação política" (RIBEIRO, Renato Janine. Hobbes: o medo e a esperança. In: WEFFORT, Francisco (Org.). Os clássicos da política: Maquiavel, Hobbes, Locke, Montesquieu, Rousseau, "O Federalista". 3. ed. São Paulo: Ática, 1991, p. 53. grifos do autor). 
Todo esse processo de formulação teórica dos modernos manifesta o esforço desses pensadores romperem com a acepção teológica e feudal de política, por intermédio da concepção antropocêntrica e racional. Segundo ela, o homem não é mais objeto de Deus, mas um ser que, dispondo de suas próprias capacidades, entre as quais a razão, é capaz de construir o seu próprio destino, a sua história.

Mais tarde, Georg Wilhelm Friedrich Hegel (1770 a 1831), por sua vez, interpretou a "sociedade civil" 2 como sendo o momento intermediário na evolução histórica da humanidade. Para Hegel, ela se situa entre a família (ocasião da unidade preliminar dos indivíduos) e o Estado (estágio superior do movimento do "espírito" no mundo), e se caracteriza como um momento em que os indivíduos abandonam a família para competir economicamente, de onde surgem as primeiras iniciativas de regulação das relações sociais, com a constituição das corporações, por exemplo.

Conforme bem anotado por Semeraro, pode-se dizer que "a maior transformação que Hegel observa [...] no mundo moderno se realiza entre o Estado - que tende a ocupar espaços políticos cada vez mais universais - e a sociedade - que se dedica, livre e autonomamente, às suas tarefas 'civis' e econômicas" (SEMERARO, 1999, p. 116). De fato, "A Revolução Industrial opera a passagem da economia para o âmbito da 'sociedade civil', relegando à família a mero espaço 'sentimental', [...] limitad[a] ao matrimônio, à propriedade e à educação dos filhos” (SEMERARO, 1999, p. 116).

Há, portanto, uma clara distinção entre sociedade civil e Estado, ou sociedade política, no pensamento de Hegel: a primeira é vista de forma negativa e caracteriza-se pela ação humana marcada pelos interesses individuais e egoístas, que são objetados pelo Estado, que conserva-supera a sociedade pré-estatal e imprime-lhe uma nova dinâmica de desenvolvimento, marcada pela universalidade real alcançada pelo "Estado, saído da Revolução Francesa, [que] é, para Hegel, 'a realidade da liberdade concreta', um evento histórico em ato [...] que o conceito de direito [...] se torna real [...] De agora em diante, fundamento da política é o direito que nasce da liberdade e se concretiza no Estado" (SEMERARO, 1999, p. 115).

Hegel diferencia-se, portanto, dos contratualistas, uma vez que entende que a "sociedade civil" é anterior ao Estado, enquanto que aqueles a concebem como manifestação do desenvolvimento político estatal, como

2 Confira-se principalmente a sua obra de maturidade, onde apresenta de forma mais acabada seu sistema filosófico-político e jurídico, qual seja a Filosofia do Direito. 
"sinônimo de 'sociedade política' (em correspondência, respectivamente, com a derivação de 'civitas' e de 'pólis') e, portanto, de Estado" (BOBBIO; MATTEUCCI; PASQUINO, 1992, p. 1206). ${ }^{3}$ Nessa perspectiva, não é o par opositor contratualista natureza/civilização (BOBBIO, 1982, p. 27), e nem, muito menos, o indivíduo desligado do todo que toma lugar nas formulações hegelianas, porquanto ele se preocupa com a dinâmica conservação/superação existente entre as relações econômicas e jurídicas (identificadas como presentes na "sociedade civil") e as relações políticas ${ }^{4}$ (propriamente estatais), bem como com "o drama profundo e a contradição marcante da sociedade moderna, dividida entre a realização da subjetividade dos indivíduos particulares, livres e emancipados e a busca da unidade e da universalidade, não mais dentro dos horizontes da integração "natural' do mundo" (SEMERARO, 1999, p. 122), mas ligados "pelo sistema das necessidades e pelo trabalho" (SEMERARO, 1999, p. 124).

Nessa fonte hegeliana que concebe o Estado como totalidade ética que histórica e concretamente precede os indivíduos, determinando seus valores, bebeu Karl Marx (1818 a 1883) ao formular o seu conceito de "sociedade civil". Porém, como se sabe, o Estado na perspectiva marxiana não é entendido como portador dessa - ou de outra - realidade essencial, explicável em si e por si mesma, mas como expressão das relações sociais de produção de um determinado e concreto momento histórico, invertendo ou subvertendo a concepção hegeliana.

No Prefácio de Para a crítica da economia política, Marx deixa isso muito claro ao afirmar que:

Minha investigação desembocou no seguinte resultado: relações jurídicas, tais como formas de Estado, não podem ser compreendidas nem a partir de si mesmas, nem a partir do assim chamado desenvolvimento geral do espírito humano, mas, pelo contrário, elas se enraízam nas relações materiais de vida, cuja totalidade foi resumida por Hegel sob o nome de

3 Diz Bobbio em BOBBIO, Norberto. O conceito de sociedade civil. 2. ed. Tradução de Carlos Nelson Coutinho. Rio de Janeiro: Edições Graal, 1982. “A inovação de Hegel com relação à tradição jusnaturalista é radical: na última redação do seu elaboradíssimo sistema de filosofia política e social, tal como aparece na Filosofia do Direito de 1821, ele se decide a chamar de sociedade civil - ou seja, com uma expressão que, até seus imediatos predecessores, servia para indicar a sociedade política - a sociedade pré-política, isto é, a fase da sociedade humana que era até então chamada de sociedade natural" (BOBBIO, 1982, p. 28 - grifos do autor).

4 Nas palavras de Bobbio temos que "A sociedade civil em Hegel é a esfera das relações econômicas e, ao mesmo tempo, de sua regulação externa, segundo os princípios do Estado liberal; e é conjuntamente sociedade burguesa e Estado burguês" (BOBBIO, 1982, p. 30). 
"sociedade civil" (bürgerliche Gesllschaft), seguindo os ingleses e franceses do século XVIII; mas que anatomia da sociedade burguesa (bürgerliche Gesllschaft) deve ser procurada na Economia Política. (MARX, 1991, p. 29).

Marx, e aqui próximo a Hegel, concebe a "sociedade civil" como o espaço das relações econômicas. Para ele "A sociedade civil compreende todo o intercâmbio material dos indivíduos numa determinada etapa do desenvolvimento das forças produtivas. Compreende toda a vida comercial e industrial de uma etapa, e nesta medida transcende o Estado e a nação" (MARX; ENGELS, 1984, p. 99), e como tal "esta sociedade civil é o verdadeiro lar e teatro da História” (MAX; ENGELS, 1984, p. 99).

É sobre essa "sociedade civil" que se projeta o Estado, que:

Adquiriu uma existência particular a par, e fora, da sociedade civil; [mesmo se sabendo que] ele nada mais é do que a forma de organização que os burgueses se dão, tanto externa como internamente, para garantia mútua da sua propriedade e de seus interesses [...] [uma] forma em que os indivíduos de uma classe dominante fazem valer os seus interesses comuns e se condensa toda a sociedade civil de uma época. (MARX; ENGELS, 1984, p. 101).

Segundo essa acepção, a "sociedade civil" identifica-se com a "sociedade burguesa", que historicamente combateu o Estado Absolutista e Mercantilista, pois limitava seu desenvolvimento e obstaculizava sua liberdade econômica. Conseguida a sua emancipação, a "sociedade civil burguesa" apropria-se do Estado e o utiliza como instrumento de defesa de seus interesses privados como classe, e não-públicos, tornando-o "um comitê para gerenciar os assuntos comuns a toda a burguesia" (MARX; ENGELS, 1997, p. 12). Assim, o Estado nada tem de "místico [...] (conceito que se autodetermina), transformando-se numa pessoa (a Consciência de $\mathrm{Si}$ )" (MARX; ENGELS, 1884, p. 60), nada tem de essência universal, tal qual se apresenta em Hegel.

Assim, diferentemente de Hegel, na acepção marxiana, o Estado ganha uma dimensão negativa, já que é visto como um instrumento de:

Dominação de classe, um órgão de submissão de uma classe por outra; é a criação de uma "ordem" que legalize e consolide essa submissão, amortecendo a colisão das classes. Para os políticos da pequena burguesia, ao contrário, a ordem é precisamente a conciliação das classes e não a 
submissão de uma classe por outra. [...] Essa democracia pequenoburguesa é incapaz de compreender que o Estado seja o "órgão" de dominação de uma determinada classe que não pode conciliar-se com sua antípoda (a classe adversa). (MARX; ENGELS, 1997, p. 10).

De fato,

O termo sociedade civil surgiu no séc. XVIII, quando as relações de propriedade já tinham se desembaraçado da comunidade antiga e medieval. A sociedade civil como tal só se desenvolve com a burguesia; a organização social que se desenvolve a partir diretamente da produção e do intercâmbio, e que em todos os tempos forma a base do Estado e da restante superestrutura idealista, continuou sempre designada com o mesmo nome. (MARX; ENGELS 1997, p. 99).

O conceito de "sociedade civil", portanto, é empregado por Marx como forma de descrever parte dos acontecimentos que levaram à passagem do modo de produção feudal ao capitalista, em que há o monopólio da política pela "sociedade civil burguesa". Sua preocupação filosófico-científica e éticopolítica era a de desvelar os fundamentos da solidariedade social que caracterizavam as relações sociais capitalistas de seu tempo, que para ele se encontram não na natureza humana e nem num elemento místico qualquer, mas na estrutura social em sua dinâmica concreta de funcionamento.

É óbvio que a genialidade teórica de Marx foi estimulada pelas enormes transformações vividas pela humanidade ao longo do século XIX, enquanto que as anteriores formulações sobre a "sociedade civil" foram:

Produzida[s] muito antes da explosão da revolução industrial e do surgimento da social-democracia. No século $\mathrm{XX}$, as velhas teorias da sociedade civil ficaram obsoletas [...] A teoria social, que começara a tomar forma na segunda metade do século XIX, abandonara a idéia de uma natureza humana ou de uma força transcendental como base para compreender o comportamento social. (SORJ, 2005, p. 15).

É nesse novo contexto que surgem novas concepções sobre o conceito de "sociedade civil", como é o caso da gramsciana.

Tendo exercitado sua militância política e desenvolvido suas concepções teóricas no princípio do século XX, Gramsci seguiu a trilha deixada por Marx no âmbito da teoria social, mas avançou para além dela. Dedicou-se, sobretudo, à tarefa de conhecer os complexos movimentos de reprodução do 
modo de vida capitalista com vista à sua superação. Foi assim que formulou interessantes conceitos, entre os quais o de "sociedade civil", um dos mais centrais em suas formulações.

Gramsci afirmava que as modernas formações econômico-sociais ocidentais são resultantes do dinâmico entrelaçamento de duas esferas societárias, a sociedade civil e a sociedade política. Pela nova acepção que conferiu ao termo "sociedade civil", esta era para ele o conjunto de aparelhos, estruturas sociais, que buscam dar direção intelectual e moral à sociedade, o que determina a hegemonia cultural e política de uma das classes sobre o conjunto da sociedade; e a sociedade política uma extensão da sedimentação ideológica promovida pela sociedade civil, que se expressa por meio dos aparelhos e atividades coercitivas do Estado, visando adequar as massas à ideologia e à economia dominantes.

Em verdade, para se reproduzir como sistema de vida hegemônico, o capitalismo procura conformar um "bloco histórico" que garanta a hegemonia da classe dominante economicamente e dirigente sob o ponto de vista éticopolítico. E faz isso utilizando tanto dos recursos e dos aparelhos de "convencimento" da sociedade civil quanto dos de coerção da sociedade política, isto é, do Estado, segundo a noção ampliada que Gramsci tem dele ("Estado = sociedade civil + sociedade política" - GRAMSCI, 1980, p. 149), numa operação mediada por diferentes atores sociais comprometidos com a conservação da realidade. Segundo suas palavras, temos que o:

Estado, que comumente é entendido como Sociedade política (ou ditadura, ou aparelho coercitivo para amoldar a massa popular ao tipo de produção e à economia de dado momento) [deve ser visto] como um equilíbrio da Sociedade política com a Sociedade civil (ou hegemonia de um grupo social sôbre a sociedade nacional inteira exercida através das chamadas organizações privadas, como a Igreja, os sindicatos, as escolas, etc. (GRAMSCI, 1987, p. 224).

Da forma ampla como é entendido por Gramsci, o Estado torna-se apto a colocar em funcionamento uma série de iniciativas - institucionalizadas ou não - capazes de reproduzir as relações sociais capitalistas, tornando as classes subalternas um conjunto de indivíduos identificados economicamente e também pela submissão que vivenciam. Ou melhor, "o Estado tem e pede o consenso, mas também 'educa' este consenso utilizando as associações políticas e sindicais, que, porém, são organismos privados deixados à iniciativa particular da classe dirigente" (GRAMSCI, 1980, p. 145). 
Porém, dessa concepção de Gramsci não resulta a neutralidade e/ ou o inatismo político-ideológico. Pelo contrário, ele não somente afirmava haver espaços - institucionalizados ou não - na sociedade para disputar a hegemonia com a classe dominante economicamente e dirigente éticapoliticamente, como também indicava como necessária a ocupação desses pelos que não concordam com as situações de subserviência vivenciadas pelas classes subalternas. Tal atitude deveria ter como tática fazer de cada espaço ocupado uma trincheira na luta contra a hegemonia da classe dominante e dirigente, visando a alterar a correlação de forças e, assim, estrategicamente ir construindo outra ordem socioeconômica e ético-política. Em outras palavras, seria necessário empreender uma "guerra de posições", colocando em prática iniciativas que contestem as estruturas e superestruturas que consolidam o status quo. Somente dessa forma é que, segundo Gramsci, consegue-se promover uma verdadeira "reforma moral e intelectual" nas sociedades de tipo "ocidental" ou do capitalismo desenvolvido, que contam com "Estados mais avançados [e com uma] sociedade civil muito complexa e resistente" (GRAMSCI, 1980, p. 73).

Desta feita, há que se considerar que a "sociedade civil" na acepção gramsciana ao mesmo tempo aproxima-se e diferencia-se da compreensão que Marx lhe tinha. As duas concepções mantêm relação de muita proximidade porque ambas entendem a "sociedade civil" como protagonista da história, ou melhor, como elemento determinante no desenvolvimento histórico. Só que para Marx, esse elemento determinante da história em última instância, a "sociedade civil", refere-se à estrutura social, enquanto que para Gramsci ela é superestrutural, mas em relação dialética com a base material. Dito de outra forma, a "sociedade civil" em Gramsci não pertence tão somente ao âmbito propriamente "econômico", com em Marx, pois se constitui justamente na articulação dialética entre infraestrutura e superestrutura jurídico-política e ideológica.

Como disse Semeraro (1999, p. 131):

Para Gramsci, a sociedade civil não está orientada em função do Estado e nem se reduz ao mundo infernal das relações econômicas burguesas, mas é principalmente o extenso e complexo espaço da moderna sociedade onde se travam os enfrentamentos ideológicos, políticos e culturais que definem a hegemonia dum grupo dirigente sobre toda a sociedade. Sem subestimar o peso das estruturas e da base econômica, Gramsci - no melhor espírito da filosofia da práxis - estabelece uma dialética relação entre sociedade civil e sociedade política e tece uma justa relação entre as condições objetivas da realidade e a vontade de organização de sujeitos ativos, capazes de construir livremente o "bloco histórico". 


\section{Considerações acerca da "sociedade civil" vista como um "terceiro setor"}

Após as primeiras considerações introduzidas pelos contratualistas e posteriormente desenvolvidas por Hegel, Marx e Gramsci sobre o conceito de "sociedade civil", ele chega ao século XXI completamente transformado em seus sentidos e revigorado pela dinâmica societária vivenciada.

Diz-se que o conceito de "sociedade civil" foi revigorado porque nos dias atuais ele ganhou tamanha conotação positiva que grande parte das ações sociais procuram ancorar-se, referenciar-se nele para adquirirem sua positividade. Demonstrar que uma ação social qualquer tem relação com a "sociedade civil" tornou-se um diferencial a empresas, governos e organizações de diferentes tipos. E pelo que se percebe, ao observar a práxis das organizações sociais de perfis distintos (leia-se ONGs, fundações, institutos, associações, cooperativas, organizações civis de diferentes formatos, empresas, etc.), quanto mais identificada com a "sociedade civil", mais uma iniciativa torna-se apta a contar com o envolvimento "voluntário" de indivíduos e com um bom tratamento dispensado pelas grandes e pequenas mídias, condições necessárias para se ter visibilidade e obter financiamentos públicos e privados.

Esse revigoramento da "sociedade civil" - se é que em algum tempo ela teve o mesmo vigor e legitimidade política e social como nos dias atuais - ocorre porque, sem dúvida, o termo "sociedade civil" teve seu significado profundamente transformado. Seus contornos são outros, muito diferentes dos até então desenhados.

Em relação a essa transformação do significado do conceito de "sociedade civil", pode-se dizer que hodiernamente ela tem duas conotações básicas, quais sejam: ao mesmo tempo em se apresenta como uma "nova" arena das ações sociais, identifica-se também com um conjunto de atores (SORJ, 2005, p. 16) bastante diferentes dos que tradicionalmente atuavam na realidade, ${ }^{5}$ como é o caso dos partidos políticos e sindicatos, por exemplo.

5 Um exemplo elucidativo da oposição anunciada sobre o tipo de intervenção social feita por atores sociais tradicionais e os "novos" pode ser conferido ao se observar os sujeitos de cada um deles, que respectivamente são o militante e o voluntário. O primeiro é o paradigma da ação social de perfil moderno, cujo engajamento e luta no processo de transformação social é princípio e finalidade de vida, enquanto que o voluntário, como o modelo de ação do "terceiro setor", engaja-se momentaneamente, sobretudo em campanhas específicas para tratar de problemas particulares, que não comprometem a sua vida e nem, muito menos, implica em riscos para o sistema social vigente, que o incorpora dinâmica reprodutiva. 
Contudo, seja com um ou com outro significado, o que torna a "sociedade civil" na acepção atualmente hegemônica diferente, inovadora para usar uma terminologia cara aos seus ideólogos -, é que ela se afirma a partir de duas negativas. De um lado, apresenta-se como independente, como neutra, como não-afinada ético-política e ideologicamente com qualquer projeto societário até então experienciado; de outro, procura se identificar como nãovinculada com o Estado e nem com o mercado.

Em se tratando da primeira negativa, pode-se dizer que a "sociedade civil", na acepção que hegemoniza atualmente seu significado, parece querer se identificar como uma esfera da sociedade ou como um tipo especial de iniciativa social que não faz uma adesão "pré-estabelecida e rígida a um determinado projeto ideológico" (RAZETO, 1999). Exibe-se como uma iniciativa social ou como um setor, um espaço, neutro ético-política e ideologicamente, isto é, nem comprometido com o capitalismo, seja ele na sua versão neoliberal (mais desumana e injusta) ou social-democrata ("mais social" e intervencionista), e nem, muito menos, com o socialismo, sobretudo pelo alegado peso histórico autoritário que esse modelo historicamente adquiriu.

Interessante observar que essa acepção de "sociedade civil" esvaziada de política ganha destaque justamente num momento em que se vive "uma estação de baixa [...] das energias societais dedicadas [...] a rever os fundamentos da comunidade política [e] conceber maneiras de tirar proveito das transformações em curso para impulsionar a construção de uma nova sociedade, situação que afeta o marxismo e o pensamento de esquerda" (NOGUEIRA, 2000, p. 115).

Com esse perfil, não é preciso muito esforço mental para entender que o conceito de "sociedade civil" em ascensão nos dias atuais, ao negar a sua natureza política, ou melhor, ao se apresentar como um "novo" e essencialmente "bom" espaço público, oposto ao "mau" espaço político tradicional (NOGUEIRA, 2000), aproxima-se muito das teses da "Terceira via": ${ }^{6}$ teoria social formulada

6 Destaque-se o livro organizado por Lúcia Maria Wanderley Neves denominado A nova pedagogia da hegemonia - estratégias do capital para educar o consenso, uma vez que, produzido pelo trabalho do Coletivo de Estudos sobre Política Educacional da Universidade Federal Fluminense, ele se dedica a justamente corroborar essa asserção de que "o neoliberalismo vem se desenvolvendo no Brasil nas últimas duas décadas por meio de um programa político específico - o programa da 'Terceira via' - [que] é ponto de partida para análise sobre a difusão, na sociedade brasileira, de novos ideais, idéias e práticas voltados para a construção de uma nova pedagogia da hegemonia: uma educação para o consenso sobre os sentidos da democracia, cidadania, ética e participação adequados aos interesses privados do grande capital nacional e internacional" (NEVES, Lúcia Maria Wanderley (Org.). A nova pedagogia da hegemonia: estratégias do capital para educar o consenso. São Paulo: Xamã, 2005). 
por Anthony Giddens (1991) e assumida por governos de diferentes nações que marcou a década de 1990. Nesse momento de arrefecimento mundial da hegemonia da ideologia neoliberal, governos autodenominados social-democratas adotaram essa orientação com a justificativa da busca de alternativas entre o (acerto do) modelo neoliberal e o (erro do) keynesianismo. Entre as suas ações concretas, destacam as que procuraram diminuir o tamanho do Estado, porque a ele caberia somente formular as políticas públicas e regular as relações sociais com agências privadas, além de estimular a criação de organizações sociais "públicas não estatais", instrumento visto pelos ideólogos da "Terceira via" como "despolitizado" e, portanto, essencialmente "bom", ao qual caberia execução do que foi formulado pelo Estado (mínimo) e pelas agências (privadas).

Especificamente no Brasil, a introdução da "Terceira via" se fez a partir das reformas do Estado implementadas (via MARE - Ministério da Administração e da Reforma do Estado, que teve à frente Luiz Carlos Bresser Pereira, de 1995 a 1998) por Fernando Henrique Cardoso. ${ }^{7}$ Com ele, deu-se início ao "processo de redefinição das estratégias destinadas a legitimar o consenso em torno da sociabilidade burguesa [...] [cujo] programa procura apresentar uma nova agenda político-econômica para o mundo nos limites do capitalismo" (NEVES, 2005, p. 43).

Ora, essa proximidade entre "sociedade civil" com a "Terceira via" contradiz a neutralidade ideológica defendida pelos ideólogos que asseveram a sua despolitização e desideologização. De modo que é possível dizer que a "sociedade civil" tem comprometimento político e ideológico, e, ademais, tal compromisso é com um projeto conservador. ${ }^{8}$

7 "O PSDB surgiu em 1988 [...] como uma dissidência do PMDB. Propôs-se inicialmente a difundir no Brasil as postulações da social-democracia clássica, mas ao longo da década de 90 atualizou seu discurso, acolhendo os postulados do neoliberalismo da Terceira via" (NEVES, 2005, p. 112).

8 Talvez dois exemplos de personalidades internacionais que participaram desse movimento da "Terceira via" sejam suficientes para corroborar o caráter conservador dele: Fernando Henrique Cardoso, do Brasil, com sua continuidade competente e limpa das operações neoliberais iniciadas por Fernando Collor de Melo, e Tony Blair, da Inglaterra, com o seu governo caracterizado pelo aprofundamento do tatcherismo, apesar de liderar o Partido Trabalhista. Esse último, aliás, teve em Giddens o seu guru político. Isso sem contar que "Falar em 'terceiro' setor tem, ademais, ressonâncias que poderiam associá-lo à 'terceira via' como concepção política que postula uma série de projetos intermediários entre o capitalismo e o socialismo" (RAZETO, Luiz. Economia de solidariedade e organização popular. In: GADOTTI, Moacir.;GUTIÉRREZ, Francisco (Org.). Educação comunitária e economia popular. 2. ed. São Paulo: Cortez, 1999. p. 34-58), mas que historicamente serviu como salvaguarda das reformas neoliberais. 
Em se tratando da segunda negativa pela qual a "sociedade civil" procura se identificar, qual seja a de que se constitui como um elemento que promove a solidariedade social para além do Estado e do mercado, há que se considerar que ela aqui se apresenta como um "novo" setor social ou, para utilizar um termo da moda, como um "terceiro setor" - o "primeiro setor" seria o público (Estado) o "segundo setor" o privado (mercado) (MONTAÑO, 1999, p. 59-60).

O discurso dos que utilizam a palavra "terceiro setor" para representar um tipo de intervenção social cujos interesses estão além dos modelos cuja sociabilidade articula-se pelo mercado ou pelo Estado esconde e revela muitas coisas. Revela que o compromisso do "terceiro setor" não é propriamente com os projetos globais de libertação ${ }^{9}$ das condições que produzem as carências de toda espécie e as vergonhosas desigualdades sociais; sobre essa questão, prefere assumir a "neutralidade", o silêncio, a indiferença, que como diz Gramsci "é o peso morto da histórica". Esconde, todavia, que os resultados de suas ações sempre fragmentárias não impactam decisivamente o status quo, tornando-se, então, dele colaboradora como ação "típica do pensamento liberal" (MONTAÑO, 1999, p. 60). Aliás, a expressão "terceiro setor" advém da língua inglesa (third sector), tendo sido utilizada inicialmente por pesquisadores no pragmático ambiente norte-americano da década de 70 do século $\mathrm{XX},{ }^{10}$ o que por si só já é revelador de muitos de seus fundamentos (liberais) e finalidades (comprometidas com a ordem burguesa).

Contudo, depois de um século cuja marca política foi, entre outras, a da "guerra fria" entre dois modelos de regulação social - o mercado capitalista e o Estado totalitário soviético -, temos hoje muitos teóricos e atores políticos que defendem a idéia de que a "sociedade civil" é um terceiro elemento

9 Aliás, é corriqueiro entre as organizações do "terceiro setor" enfrentar os problemas empiricamente, mas sem produzir uma crítica mais radical deles. Isso feito, acredita-se, resultaria em um questionamento do sistema global de vida, o que não é próprio do "terceiro setor", que "[...] é pouco ou nada politizad[o], na maioria das vezes avesso às ideologias e integrado às políticas neoliberais." (GOHN, Maria da Glória. Educação não-formal e cultura política: impactos sobre o associativismo do terceiro setor. São Paulo: Cortez, 1999. p. 18).

10 Na década seguinte - 1980 -, nos EUA, o “terceiro setor" era designado pela expressão nonprofit sector, que todavia manifesta "o individualismo liberal que caracteriza o regime político e a cultura de lá, no qual o ideário dominante é o da precedência da sociedade em relação ao Estado e o associativismo e o voluntarismo estão fortemente arraigados na cultura" (FERREIRA, Victor Cláudio Paradela. ONGs no Brasil: um estudo sobre suas características e fatores que têm induzido seu crescimento. 2005. 271 f. Tese (Doutorado na escola de Administração Pública e de Empresas da FGV) - FGV - Fundação Getúlio Vargas, Rio de Janeiro: 2005. p. 33). 
articulador das relações sociais, não-maculado pelos pecados do insaciável e desumano mercado e nem pela ineficiência, "vilania" e autoritarismo estatal. ${ }^{11}$ Essa, entrementes, não é outra coisa senão uma proposição muito adequada às necessidades de reprodução do capital, pois:

Como as reformas do Consenso de Washington não produziram os resultados esperados e se faziam necessárias novas idéias para transformar as instituições sociais, a sociedade civil atendeu à demanda por um conceito maleável com uma interferência indireta na política local e com apoio tanto da direita quanto da esquerda. (SORJ, 2005, p. 10).

Assim sendo, formada por organizações sociais institucionalizadas ou não - e mesmo por indivíduos que voluntariamente (essa é uma palavra muito significativa à "sociedade civil" contemporânea e, como não poderia deixar de ser, às propostas da "Terceira via") se organizam para produzir bens e serviços de acordo com os problemas empíricos localizados, aquilo que se entende por "sociedade civil" costuma estabelecer parcerias com o Estado e/ou com empresas privadas, segue suas agendas ou mesmo depende cada vez mais de seus recursos. ${ }^{12}$ Do que decorre a insustentabilidade da tese

11 Essa concepção, então, "Demoniza o espaço político para a ele atribuir toda a culpa pelos pecados que maculariam a natureza virtuosa da sociedade civil, vítima indefesa e permanentemente prejudicada pela vilania estatal" (NOGUEIRA, Marco Aurélio. Gramsci desembalsamado - em torno dos abusos do conceito de sociedade civil. Educação em foco, Juiz de Fora, v. 05, n. 02, 2000. p. 118).

12 Sobre essa questão é muitíssimo interessante conferir o trabalho de Bernardo Sorj, denominado Sociedades Civis e relações Norte-Sul: ONG's e dependência. Neste texto, o autor defende a idéia de que "a mais forte expressão da sociedade civil nos países em desenvolvimento, as ONGs independentes, embora compartilhem elementos comuns com suas equivalentes em países avançados, são ONGs dependentes. O conceito de dependência foi elaborado principalmente por cientistas sociais latino-americanos para caracterizar como países em desenvolvimento aqueles cujas estruturas econômicas carecem de capacidade de produzir localmente inovação tecnológica. Por extensão, definimos como dependentes as organizações da sociedade civil cuja principal fonte de financiamento e agenda vêm dos países avançados" (SORJ, Bernardo. Sociedades civis e relações Norte-Sul: ONGs e dependência. Tradução de Plínio A. Dentzien, Rio de Janeiro: Jorge Zahar, 2005. Disponível em: <http://www. centro edelstein.org.br>. Acesso em: 18 nov. 2005, p. 3-4 - grifos do autor). Ainda acerca da dependência direta ou indireta das organizações não-governamentais dos recursos estatais, Cf. o artigo de (HOROCHOVSKI, Rodrigo Rossi. Associativismo civil e Estado: um estudo sobre organizações não-governamentais (ONGs.) e sua dependência de recursos públicos. Revista Eletrônica dos Pós-Graduandos em Sociologia Política da UFSC, Florianópolis, v. 1, n. 1, p. 109-127, ago./dez. 2003). 
que afirma que a "sociedade civil" constitui-se como um "terceiro setor", ${ }^{13}$ como um elemento independente, não-afetado pelos conflitos e contradições que marcam a realidade econômica e política.

Enfim, mesmo sendo difícil a identificação político-ideológica da "sociedade civil" em geral (pois dela participam várias espécies de organização social, que executam diferentes projetos, cada qual com seus fundamentos, perspectivas e métodos, que variam de realidade local para realidade local), entendida a partir das negativas que apresentam a sua acepção hegemônica atualmente, é possível confirmar a sua afinidade com a "Terceira via" de Giddens (2000) e contestar a sua identidade como sendo a de um "terceiro setor".

Essa conclusão contradiz a ingênua - para não dizer manipuladora e interesseira - assertiva da despolitização e da desideologização da "sociedade civil". Na verdade, esse movimento que promove ações filantrópicas, o voluntariado, a responsabilidade social das empresas, isto é, os "vários aspectos [desse] novo trato [que está sendo dado] à questão social" (MONTAÑO, 1999, p. 62 - grifos do autor ${ }^{14}$ é um produto histórico que decorre das condições objetivas e subjetivas, hoje marcadas pela reestruturação produtiva ${ }^{15}$ do capital e pela crise do Estado, que no Brasil abriram caminho para a sua modernização conservadora.

13 Interessante observar, porém, que é justamente a imprecisão de sua própria identidade que identifica o "terceiro setor" como aquele que "pode convocar quase a todos " (RAZETO, 1999, p. 4 - grifos do autor), sem a sua necessária adesão "pré-estabelecida e rígida a um determinado projeto ideológico" (RAZETO, 1999, p. 4). Paradoxalmente, portanto, a identidade ideológica do "terceiro setor" está justamente no discurso da negação ideológica, que há muito é conhecido como uma das formas de reprodução do modo de produção da vida social, pois que "numa determinada sociedade ninguém é desorganizado e sem partido, desde que se entendam organização e partido num sentido amplo, e não formal" (GRAMSCI, Antonio. Maquiavel, a política e o estado moderno. Tradução de Luiz Mário Gazzaneo. 4. ed. Rio de Janeiro: Civilização Brasileira, 1980. p. 151).

${ }^{14}$ Cf. também toda a parte "3" desse texto de Montaño, que vai da página 60 a 74, denominado "O novo trato à 'questão social': precarização, re-mercantilização e re-filantropização - o retorno do passado".

15 Cf. o texto de Celso Ferreti (Org.). Novas tecnologias, trabalho e educação - um debate multidisciplinar, e também dois outros de (ANTUNES, Ricardo. Reestruturação produtiva e mudanças no mundo do trabalho numa ordem neoliberal. In: DOURADO, Luiz Fernando; PARO, Vitor Henrique (Org.). Políticas públicas \& educação básica. São Paulo: Xamã, 2001), quais sejam a Reestruturação produtiva e mudanças no mundo do trabalho numa ordem neoliberal e $\mathrm{O}$ desenho multifacetado do trabalho hoje e sua nova morfologia (ANTUNES, Ricardo. O desenho multifacetado do trabalho hoje e sua nova morfologia. Serviço social \& Sociedade, São Paulo, ano 23, n. 69, p. 107-120, 2002. 


\section{Apropriações (indébitas) do conceito de "sociedade civil" em Gramsci}

Ao tomar conhecimento das assertivas que sustentam a acepção liberal que a "sociedade civil" adquiriu como "Terceira via" ou "terceiro setor", é possível observar que alguns autores são chamados mais recorrentemente a fundamentar suas teses, projetos e ações sociais. Entre eles, destacam-se Tocqueville, com o seu "comunitarismo", Habermas, com a sua perspectiva de construção de um novo espaço público mediante o consenso estabelecido pelo diálogo entres diferentes - e por que não dizer contraditórios - sujeitos sociais (porquanto para esse autor a categoria de classe social não é mais vista como fundamento epistemológico e ético-político), e Gramsci, com seu conceito de "sociedade civil".

Centrando a discussão ${ }^{16} \mathrm{em}$ Gramsci - até mesmo porque esse é o objeto do presente texto - é possível dizer ainda mais: muitos dos que pertencem àquilo que se identifica como sendo o "terceiro setor" costumam fundamentar sua práxis nas formulações que Gramsci tem acerca da "sociedade civil". Ora, até mesmo a leitores iniciantes na obra do comunista revolucionário italiano é muito difícil não estranhar a apropriação liberal feita de suas formulações acerca da "sociedade civill. Senão vejamos.

Muito embora tenha vivido em outro período histórico, Gramsci teve a possibilidade de vivenciar o começo do processo que fez o capitalismo ganhar os inusitados e complexos contornos atuais. Em suas perspicazes observações e intervenções na realidade, ele chegou a formular conceitos que ainda mantêm capacidade heurística suficiente para nos auxiliar na tarefa de desvendar a dinâmica societária capitalista.

Se considerarmos, como indicou Gramsci, que as modernas formações sociais ocidentais são resultantes históricas das transformações econômicas bem como do dinâmico imbricamento de duas esferas societárias, a "sociedade civil" e a sociedade política, poderemos identificar a práxis desenvolvida pelo assim (equivocadamente) chamado de "terceiro setor" como

16 Para se acompanhar uma boa discussão sobre a forma como esses e outros autores são utilizados como fundamento teórico do "terceiro setor", a obra de Montaño denominada Terceiro setor e questão social - crítica ao padrão emergente de intervenção social, principalmente seu Capítulo I. 
uma ação da "sociedade civil", ou melhor, dos aparelhos privados de hegemonia que, respaldada por "intelectuais", ${ }_{17}^{17}$ resulta na manutenção e consolidação do "bloco histórico" 18 resultante da situação histórica que hoje se vivencia.

De fato, para se reproduzir como sistema de vida hegemônico, o capitalismo procura conformar um "bloco histórico" que garanta a hegemonia da classe dominante economicamente e dirigente no sentido ético-político. E faz isso utilizando os recursos e os aparelhos da "sociedade civil" e da sociedade política, numa operação mediada pelos intelectuais comprometidos com manutenção do modelo de sociabilidade presente.

Isso coloca em funcionamento uma série de iniciativas estatais e não-estatais capazes de reproduzir as relações sociais capitalistas, tornando as classes subalternas um conjunto de indivíduos identificados economicamente e também pela submissão que vivenciam. Entre essas iniciativas encontram-se as do "terceiro setor", pois que seus empreendimentos procuram garantir o "bom" funcionamento do sistema de vida, forjando nas classes subalternas um padrão de comportamento ético-político adequado à lógica econômica vigente, incorporando-se a ela e retroalimentando-a.

17 Nas palavras de Gramsci temos que "Cada grupo social, nascendo no terreno originário de uma função essencial no mundo da produção econômica, cria para si, ao mesmo tempo, de um modo orgânico, uma ou mais camadas de intelectuais que lhe dão homogeneidade e consciência da própria função, não apenas no campo econômico, mas também no social e político" (GRAMSCI, Antonio. Concepção dialética da história. Tradução de Carlos Nelson Coutinho. 10. ed. Rio de Janeiro: Civilização Brasileira, 1995a. p. 3). Em outra passagem, afirma "tarefa dos intelectuais é determinar e organizar a reforma moral e intelectual, isto é, adequar a cultura à função prática" (GRAMSCI, 1995a, p. 178).

18 Considerada como uma das formulações mais centrais na obra gramsciana (PORTELLI, Hugues. Gramsci e o bloco histórico. Tradução de Angelina Peralva. 5. ed. Rio de Janeiro: Paz e Terra, 1990. p. 15), o conceito de bloco histórico constitui-se como uma formulação com alta capacidade heurística, sobretudo em se tratando da tarefa de desvelar as relações sociais nas modernas formações ocidentais. Com ele é possível a Gramsci compreender que a dinâmica societária institui-se na relação dialética e orgânica que se estabelece entre estrutura e superestrutura, inovando algumas leituras economicistas e mecanicistas do legado marxiano. Nessa relação, a classe dominante no nível estrutural, istoé, a dominante economicamente procura assegurar por diferentes meios (como os da sociedade civil e da sociedade política) que seus interesses e suas necessidades como classe prevaleçam nas relações sociais, tornando-se hegemônica sobre o conjunto social. O "bloco ideológico" aí formado torna possível à classe dominante ser dirigente sob o ponto de vista ético-político, do que resulta que seus interesses e visões de mundo tornam-se universais, isto é, de todos os integrantes das demais classes, inclusive das subalternas. Quando isso acontece dizse que se configurou um bloco histórico, porquanto esse tem a capacidade histórica de dirigir a formação social diante dos percalços que surgem na sua vida concreta. 
Assim entendido o conceito de "sociedade civil" por Gramsci, não haveria qualquer possibilidade de ele ser utilizado como fundamento teórico para o que se identifica hoje como "terceiro setor". Isso porque, pelo que se observa da acepção que Gramsci confere ao conceito de "sociedade civil", ele não é nem independente do Estado e do mercado e nem, muito menos, despolitizado ou desideologizado. Pelo contrário, visto como um dos elementos que compõem a relação orgânica e dialética que se estabelece entre estrutura e superestrutura social, ele se apresenta não só como espaço político para se disputar a hegemonia em uma formação social ocidental específica, como também como um recurso heurístico para melhor se compreender e analisar quais os contornos do "bloco histórico" em sua dinâmica concreta.

Contudo, há que se considerar que tal interpretação da "sociedade civil" não é única que se tem do assistemático legado teórico-filosófico e éticopolítico gramsciano, uma vez que essa questão da conceituação da "sociedade civil" no interior da obra de Gramsci sempre foi muito controversa, sobretudo porque é recorrente a sua leitura idealista-liberal. ${ }^{19}$ De fato, há outras leituras das formulações gramscianas sobre a "sociedade civil" que abrem espaço para apropriações indébitas da herança deixada pelo comunista revolucionário da Sardenha, como é o caso da feita por Bobbio.

Muito embora "A Bobbio deva ser reconhecido o mérito de ter posto em evidência a originalidade e a fecundidade que o conceito de sociedade civil representa no pensamento de Gramsci" (SEMERARO, 1999, p. 183), sua leitura das formulações desse comunista italiano apresenta sérios problemas, que comprometem sua coerência com o conjunto da obra gramsciana. O mais significativo deles é que Bobbio produziu sobre o pensamento de Antonio Gramsci uma interpretação pouco dialética da relação entre a estrutura e a superestrutura.

Bobbio, em seu famoso texto chamado de $O$ conceito de sociedade civil, desvirtua a concepção dialética que Gramsci tem da relação estruturasuperestrutura já que afirma ser o revolucionário sardenho um intelectual que teria "colocado "o verdadeiro centro, o teatro da história"” (BOBBIO, 1982, p. 33) na "sociedade civil, [que] em Gramsci, não pertence ao momento da

19 Essa afirmação não deve ser interpretada como um desconhecimento do fato de que Gramsci, sobretudo em sua juventude, inegavelmente bebeu em fontes idealistas e liberais. Sobre essa questão há que se considerar a influência que Croce e Gentile tiveram na práxis e no pensamento gramsciano, utilizados inclusive como forma de o revolucionário comunista sardenho se contrapor às interpretações mecanicistas e economicistas hegemônicas no movimento marxista do início do século XX. 
estrutura, mas ao da superestrutura." (BOBBIO, 1982, p. 32). E mais ainda, diz ele que "Na realidade, ao contrário do que se crê, Gramsci deriva o seu conceito de sociedade civil não de Marx, mas declaradamente de Hegel", o que seria suficiente, sob esse ponto de vista, para Gramsci não ser considerado um materialista histórico e dialético, mas um idealista, um novo Croce.

Essa posição de Bobbio sobre a concepção que Gramsci tem da relação estrutura-superestrutura é sustentada principalmente em "uma passagem fundamental de um dos textos mais importantes dos Cadernos" (BOBBIO, 1982, p. 32), publicado na Parte I - Contribuição para uma história dos Intelectuais de Os Intelectuais e a organização da cultura; eis a passagem:

Por enquanto, pode-se fixar dois grandes "planos" superestruturais: o que pode ser chamado de "sociedade civil" (isto é, o conjunto de organismos chamados comumente de "privados") e o da "sociedade política ou Estado", que correspondem à função de "hegemonia" que o grupo dominante exerce sobre toda a sociedade e àquela de "domínio direto" ou de comando, que se expressa no Estado e no governo "jurídico". (GRAMSCI, 1995b, p. 110-11).

Além dessa, mais adiante, Bobbio também destaca outra passagem dos Cadernos que, segundo ele, corroboraria a sua interpretação de que a "sociedade civil" em Gramsci é mais herdeira de Hegel do que de Marx. Tal passagem encontra-se publicada em Passato e presente e diz que: "sociedade civil como é entendida por Hegel e no sentido em que é empregada nestas notas (isto é, no sentido de hegemonia política e cultural de um grupo social sobre toda a sociedade, como conteúdo ético do Estado)" (GRAMSCI, 1979, p. 214-215). Este trecho dos Cadernos é suficiente, segundo Bobbio, "para esclarecer dois pontos muito importantes: "1) o conceito gramsciano de sociedade civil pretendese derivado do de Hegel; 2) o conceito hegeliano de sociedade civil, tal como Gramsci o concebe, é um conceito superestrutural" (BOBBIO, 1982, p. 34).

Ao avaliar mais detidamente as duas passagens destacadas por Bobbio, há que se contestar sua interpretação. Isso porque, além de o próprio revolucionário sardenho afirmar que "deve-se realizar, com relação à concepção filosófica de Croce, a mesma redução que os primeiros teóricos da filosofia da praxis realizaram com a concepção hegeliana" (GRAMSCI, 1995a, p. 229 grifo do autor), Bobbio parece desconhecer que para Gramsci o que há entre estrutura e superestrutura é uma relação dialética, ou melhor, um nexo marcado por relações concretas, o que impossibilita qualquer separação abstrata que se possa fazer, qualquer isolamento de um ou de outro elemento. 
Como bem disse Portelli, "A análise separada de cada uma das duas esferas do momento superestrutural não corresponde, evidentemente, à realidade prática" (PORTELLI, 1977, p. 32). Apesar disso, o que fez o liberal Bobbio foi justamente analisar em separado a "sociedade civil", desconhecendo que na prática social essa separação entre "sociedade civil" e sociedade política não existe de fato, e tão pouco para a filosofia da práxis, uma vez que, segundo Gramsci, "não é verdade que a filosofia da praxis 'destaque' a estrutura das supra-estruturas; ao contrário, ela concebe o desenvolvimento delas como intimamente relacionado e necessariamente inter-relativo e recíproco" (GRAMSCI, 1995a, p. 263).

De fato:

Gramsci não é um idealista, não supõe uma separação entre o mundo da vida e o mundo da política nem transfere o poder de determinação para o plano político-ideológico, para a sociedade civil. Ao contrário, preocupase sempre em ressaltar os elementos de identidade/distinção que fazem com que estrutura e superestrutura (e, no interior dessa, a sociedade civil e a sociedade política) possam ser vistas como partes de um mesmo "bloco histórico". (NOGUEIRA, 2000, p. 117).

A rigor, se bem interpretadas as considerações de Gramsci, só se pode concluir que elas afirmam que o que existe realmente entre "sociedade civil" e sociedade política é uma relação profundamente articulada, "um nexo necessário e vital" (NOGUEIRA, 2000, p. 271), que Gramsci expressa em um outro conceito seu de grande valor heurístico, qual seja o bloco histórico: "O conceito do valor concreto (histórico) das superestruturas na filosofia da praxis deve ser aprofundado, relacionando-o ao conceito soreliano de bloco histórico" (idem), definido por Gramsci como sendo a "unidade entre natureza e o espírito (estrutura e superestrutura) unidade dos contrários e dos distintos" (GRAMSCI, 1980, p. 12).

Sem reconhecer a concretude e a dialética relação entre estruturasuperestrutura e sem operar epistemologicamente com essas suas características, fica deveras fácil fazer as inferências que Bobbio fez. Contudo, não há interpretação formal-analítica do pensamento gramsciano que resista aos seus conceitos caracteristicamente dialéticos e concretos, como é o caso do de bloco histórico, que expressa com precisão a relação existente entre estrutura e superestrutura. E sobre essa questão Gramsci não deixa qualquer dúvida, pois afirma que "A estrutura e as superestruturas formam um 'bloco histórico', isto é, o conjunto complexo - contraditório e discordante - das superestruturas é o reflexo do conjunto das relações sociais de produção" (GRAMSCI, 1995a, p. 52). 
Apesar dessa clareza com que o comunista italiano apresenta a sua concepção dialético-concreta, é compreensível a interpretação mais do que enviesada feita por Bobbio, uma vez que, inegavelmente, há entre eles:

Diferenças e contradições [...] muito [...] profundas. E não se trata só de questões de forma e de método: Bobbio é um intelectual mais acadêmico, que privilegia o método analítico e a esquematização conceitual, enquanto Gramsci é um intelectual mais político, que lança mão do método dialético e da filosofia da práxis [...] Bobbio e Gramsci devem ser considerados como representantes das expressões mais elaboradas do liberalismo e do socialismo, duas concepções de homem e de mundo que, não obstante sucessivas modificações e tentativas de aproximações, se mantiveram substancialmente inconciliáveis. (SEMERARO, 1999, p. 204). ${ }^{20}$

Em síntese, pode-se dizer que a leitura liberal bobbiana equivocase por não reconhecer as peculiaridades do materialismo, do historicismo e da dialética gramscianos, que concebem a "sociedade civil" como o "dinâmico, complexo e moderno campo da ação política, econômica, social e cultural, onde as classes subjugadas são chamadas a empenhar as lutas decisivas para se

${ }^{20}$ Feita essa consideração de cunho epistemológico e ético-político das diferenças entre as reflexões de Bobbio e o que realmente representa Gramsci e seus escritos, em seu texto denominado Gramsci e a sociedade civil, Semeraro avança n'A leitura de Norberto Bobbio, sobretudo em seu Capítulo 5. Neste, Semeraro chega até mesmo a reconhecer em Bobbio "o mérito de ter posto em evidência a originalidade e a fecundidade que o conceito de sociedade civil representa no pensamento de Gramsci" (SEMERARO, Giovanni. Gramsci e a sociedade civil: cultua e educação para a democracia. Petrópolis: Vozes, 1999. p. 183) Mas, não deixa de tecer as suas críticas às "lacunas e ambigüidades que precisam ser desvendadas, para não se cair em armadilhas (SEMERARO, 1999, p. 184). Só para ilustrar com exemplos algumas dessas "lacunas e ambigüidades" apontadas por Semeraro, podemos citar: 1) o "fato de Bobbio não ter evidenciado, juntamente com as derivações, as profundas diferenças entre Gramsci e o pensamento hegeliano" (SEMERARO, 1999, p. 184), podendo o leitor ser induzido "a crer que a verdadeira fonte de Gramsci é a Filosofia do Direito de Hegel e não a Crítica da economia política de Marx" (SEMERARO, 1999, p. 2) "Bobbio tenta uma redução economicista das posições de Marx. Naturalmente, ao apresentar Marx como teórico da estrutura, por antinomia, ficava mais fácil apresentar Gramsci como teórico das superestruturas" (SEMERARO, 1999, p.185); 3) "as distinções [feitas por Bobbio [...] entre estrutura e superestrutura [...] são de caráter metódico, e não orgânico"; 4) Bobbio desconhece que "Gramsci parte dos pressupostos de Marx e Lênin [...] destaca[ndo que] juntamente com a transformação econômica da realidade já existia neles um núcleo essencial que remetia à importância das frentes ideológicas e culturais" (SEMERARO, 1999, p. 188); 5) "Bobbio desliga a sua análise da sociedade civil do conjunto do pensamento de Gramsci” (SEMERARO, 1999, p. 188). 
constituir como sujeitos" (SEMERARO, 1999, p. 216) de sua própria história e protagonistas do destino da formação social da qual fazem parte.

É nesta perspectiva idealista, a-histórica e pouco dialética que Gramsci é tomado como fundamento daquilo que se concebe hoje como "sociedade civil", um campo ou um conjunto de ações que se desenvolve completamente isolado da estrutura social, do Estado ou do mercado e, portanto, visto como completamente neutro. Obviamente que isso é uma apropriação indébita do legado materialista histórico e dialético gramsciano, que se esforçou sobremaneira para tentar captar a realidade concreta em seus imbricados, orgânicos e dialéticos contornos (sem qualquer isolamento de um aspecto da realidade, como a "sociedade civil", por exemplo), para que pudesse ter melhores condições de empreender ações de superação do capitalismo, isto é, com um claro compromisso ético-político e ideológico, negado por aqueles que concebem a "sociedade civil" como um "terceiro setor", fundamentando-se recorrentemente nas teses da "Terceira via".

Enfim, do que foi dito resulta uma conclusão evidente, que não poderia ser melhor expressa senão pelas mesmas palavras já enunciadas por Nogueira ao analisar os usos e os abusos que hoje se faz do conceito de sociedade civil. Diz ele, e aqui se reitera, que:

Não há sentido em opor ao "excesso de Estado" uma lógica "sociolatra" baseada na valorização unilateral dos movimentos sociais, dos novos tipos de associativismo, das organizações não-governamentais, do "terceiro setor", da defesa meio anárquica dos processos de descentralização, das "justiças emergentes", e assim por diante. Trata-se de uma espécie de apologia da sociedade civil que nada tem de gramsciana (nem, portanto, de marxista). (NOGUEIRA, 2000, p. 129).

\section{Referências}

ANTUNES, Ricardo. Reestruturação produtiva e mudanças no mundo do trabalho numa ordem neoliberal. In: DOURADO, Luiz Fernando; PARO, Vitor Henrique (Org.). Políticas públicas \& educação básica. São Paulo: Xamã, 2001.

O desenho multifacetado do trabalho hoje e sua nova morfologia. Serviço Social \& Sociedade, São Paulo, ano 23, n. 69, p. 107-120, 2002. 
BOBBIO, Norberto. O conceito de sociedade civil. 2. ed. Tradução de Carlos Nelson Coutinho. Rio de Janeiro: Edições Graal, 1982.

BOBBIO, Norberto; MATTEUCCI, Nicola; PASQUINO, Gianfranco. Dicionário de política. Tradução de Carmen C. Varrialle e outros. 4. ed. Brasília: Universidade de Brasília, 1992, v. 1 e 2.

FERNANDES, Rubem César. Privado porém público: o terceiro setor na América Latina. Rio de Janeiro: Relume Dumará, 1994.

FERREIRA, Victor Cláudio Paradela. ONGs no Brasil: um estudo sobre suas características e fatores que têm induzido seu crescimento. 2005. $271 \mathrm{f}$. Tese (Doutorado na escola de Administração Pública e de Empresas da FGV) Fundação Getúlio Vargas, Rio de Janeiro, 2005.

FORTES, Luiz R. Salinas. Rousseau: o bom selvagem. São Paulo: FTD, 1989.

GIDDENS, Anthony. As consequiências da modernidade. Tradução de Raul Fiker. 2. ed. São Paulo: UNESP, 1991.

A terceira via: reflexões sobre o impasse político atual e o futuro da social-democracia. Tradução de Maria Luisa S. de A. Borges. Rio de Janeiro: Record, 2000.

GOHN, Maria da Glória. Educação não-formal e cultura política: impactos sobre o associativismo do terceiro setor. São Paulo: Cortez, 1999.

GRAMSCI, Antonio. Passato e presente. I edizione ristampa. Roma: Riuniti, 1979.

Maquiavel, a política e o estado moderno. Tradução de Luiz Mário Gazzaneo. 4. ed. Rio de Janeiro: Civilização Brasileira, 1980.

Literatura e vida nacional. Tradução de Carlos Nelson Coutinho. 2. ed. Rio de Janeiro: Civilização Brasileira, 1987.

Concepção dialética da história. Tradução de Carlos Nelson Coutinho. 10. ed. Rio de Janeiro: Civilização Brasileira, 1995a.

Os intelectuais e a organização da cultura. Tradução de Carlos Nelson Coutinho. 9. ed. Rio de Janeiro: Civilização Brasileira, 1995 b. 
HOROCHOVSKI, Rodrigo Rossi. Associativismo civil e Estado: um estudo sobre organizações não-governamentais (ONGs.) e sua dependência de recursos públicos. Revista Eletrônica dos Pós-Graduandos em Sociologia Política da UFSC, Florianópolis, v. 1, n. 1, p. 109-127, ago./dez. 2003.

LOCKE, John. Ensaio acerca do entendimento humano. Tradução de Anoar Aiex. 5. ed. São Paulo: Nova Cultural, 1991. v. 9. (Coleção Os Pensadores).

MARX, Karl. Prefácio: para a crítica da economia política. In: MARX, Karl. Manuscritos econômicos e filosóficos e outros textos escolhidos. Tradução de José Carlos Bruni e outros. 5. ed. São Paulo: Nova Cultural, 1991. v. 12. (Coleção Os Pensadores).

MARX, Karl. ENGELS, Friedrich. A ideología alemã: $1^{\circ}$ capítulo seguido das teses de Feuerbach. São Paulo: Moraes, 1984.

; ENGELS, Friedrich. A ideologia alemã: $1^{\circ}$ capítulo seguido das teses de Feuerbach. São Paulo: Moraes, 1997.

MONTAÑO, Carlos. Das "lógicas do Estado" às "lógicas da sociedade civil": Estado e "terceiro setor" em questão. Serviço Social \& Sociedade, São Paulo, ano 20, n. 59, p. 47-79, mar. 1999.

NEVES, Lúcia Maria Wanderley (Org.). A nova pedagogia da hegemonia: estratégias do capital para educar o consenso. São Paulo: Xamã, 2005.

NOGUEIRA, Marco Aurélio. Gramsci desembalsamado - em torno dos abusos do conceito de sociedade civil. Educação em foco, Juiz de Fora, v. 5, n. 2, p. 115-130, 2000.

PORTELLI, Hugues. Gramsci e o bloco histórico. Tradução de Angelina Peralva. 5. ed. Rio de Janeiro: Paz e Terra, 1990.

RAZETO, Luiz. Economia de solidariedade e organização popular. In: GADOTTI, Moacir; GUTIÉRREZ, Francisco (Org.). Educação comunitária e economia popular. 2. ed. São Paulo: Cortez, 1999. p. 34-58.

. La dimension economica del terceiro sector en America Latina. 1999. Disponível em: $<$ http: //www.rits.org.br/frames/index_frames_geral.cfm?palavra= /acervo/acervo_pesquisa.cfm?CABECALHO>. Acesso em: 07 set. 2005. 
RIBEIRO, Renato Janine. Hobbes: o medo e a esperança. In: WEFFORT, Francisco (Org.). Os clássicos da política: Maquiavel, Hobbes, Locke, Montesquieu, Rousseau, “O Federalista”. 3. ed. São Paulo: Ática, 1991. p. 51-77.

SEMERARO, Giovanni. Gramsci e a sociedade civil: cultua e educação para a democracia. Petrópolis, RJ: Vozes, 1999.

SORJ, Bernardo. Sociedades civis e relações Norte-Sul: ONGs e dependência. Tradução de Plínio A. Dentzien, Rio de Janeiro: Jorge Zahar, 2005. Disponível em: <http://www.centro edelstein.org.br>. Acesso em: 18 nov. 2005.

\section{Bibliografia complementar}

HEGEL, Friedrich. Fenomenologia do espírito. In: Os Pensadores - Husserl e Hegel: Investigações lógicas: Sexta investigação - elementos de uma elucidação fenomenológica do conhecimento. Seleção e Tradução de Zeljko Loparic e Andréa Maria Altino de campos Loparic. A fenomenologia do espírito. Trad. de Henrique Cláudio de Lima Vaz. 5. ed. São Paulo: Nova Cultural, 1992. v. 2.

SILVA, Felipe Luiz Gomes. O que é o terceiro setor? 2003. Disponível em: <http:/ /www.rits.org.br/acervo/_pesquisa_detalhe.cfm?CA=2003\&Primeiro_Reg_pag>. Acesso em: 07 out. 2005.

Recebido: $12 / 02 / 2008$

Received: 02/12/2008

Aprovado: 02 /03/2008

Approved: 03/02/2008 